\title{
FRAMED BY FREEDOM: Emancipation and Oppression in Post-Fordist Thailand
}

\author{
CLAUDIO SOPRANZETTI \\ University of Oxford \\ (D) http: / / orcid.org/0000-0002-6044-9147
}

Freedom is a project . . . flanked by the problem of power on all sides: the power against which it arrays itself as well as the power it must claim to enact itself.

-Wendy Brown

Seen from above, Bangkok resembles an octopus, scarred on its left side by the sinuous bends of the Chao Praya River and squeezed in the middle, with its tentacles distending sideways. Zooming in, the structure of the city starts to break down, and the octopus contorts into cramped and convoluted patterns. Long and narrow streets branch out of the major roads and conquer the space between them without connecting. Every morning, the city wakes up from these small alleys (soi): the octopus moving the tips of its tentacles. Inhabitants and their children flood into the city center, where most of them work but cannot afford to live. Small vans, collective taxis, and buses ferry the working class through the complex maze of radial roads and branching streets, all the way to their workplaces. Those who have the means take taxis, or their own cars, to the underground or to an elevated mass-transit terminus, and continue their commutes inside air-conditioned trains. People living along the few remaining navigable canals jump on slim longboats and endure the pungent smell of the waterways in exchange for bypassing traffic. Nonetheless, even in a city that serves different 
locations, capacity to pay, and levels of rush with multiple modes of transportation, few of them are able to reach deep into the maze of soi, where most of Bangkok's city dwellers live. Mobility inside those alleys - too narrow for buses, vans, and the Skytrain, and often clogged with cars - remains largely in the hands of motorcycle taxi drivers who arrive at their street corners every morning, just before the city revives.

Bangkok is traversed every day by two hundred thousand of these drivers, most of them migrant men from outer provinces. Collectively, they operate between four to six million trips per day, roughly ten times the number of trips traveled by Bangkok's subway and Skytrain combined. ${ }^{1}$ Perched on their seats, the city keeps moving, even during its infamous traffic jams. While many of the drivers arrived in Bangkok with dreams and desires that went beyond allowing its population and commodities to circulate smoothly (Sopranzetti 2012), they eventually took up their occupation through personal and collective paths that aligned with those of Thai capitalism in the past two decades. Most important, the massive layoffs that followed the 1997 crisis (addressed in what follows), combined with a difficult adjustment to the discipline of labor in the factories where many migrants found themselves after having landed in Bangkok, compelled them to become drivers. If these causes brought them to the job, itsaraphapp (freedom, independence), ${ }^{2}$ many of the drivers like to repeat, is what keeps them in this hectic, stressful, and health-threatening occupation. The drivers acknowledge job insecurity and the risks of road accidents, and they often resort to the protection of amulets and magic tattoos (Sopranzetti, forthcoming). Nonetheless, they insist - as do many other workers in the urban service economy - that the job's 'itsaraphāp makes up for the precarity of their labor. ${ }^{3}$ As Yai, the vice president of the Association of Motorcycle Taxis of Thailand (AMTT) told me, staring into my eyes, "motorcycle taxi drivers die young, but live free."

This article examines the discourse of freedom among the drivers as both an emancipatory and an oppressive force. 'Itsaraphap, I show, is emerging as a central framework through which to understand life in contemporary Thailand. It is by mobilizing this principle that self-employed and precarious workers make sense of and make do with political-economic, social, and conceptual shifts taking place around them by casting themselves as successful migrants, entrepreneurial subjects, and autonomous urban dwellers. In this sense, the drivers adopt 'itsaraphāp to reconcile their personal desires and aspirations with the changing structural configurations of capital and labor in post-crisis Thailand. To show this process, in the first section of this article I focus on the drivers' experience since 
the 1997 crisis and their formulation of freedom. In the second section, I show how this formulation relates to larger political-economic shifts in the Thai economy toward post-Fordism during the past two decades. ${ }^{4}$ It is only when juxtaposing the two dimensions - that of experience and of political economy - and exploring their entanglements, as I do in the conclusion, that the significance of freedom in contemporary Thailand is revealed.

\section{TOWARD AN ANTHROPOLOGY OF FREEDOM}

The paradox of freedom as both an emancipatory and an oppressive force has been extensively studied, both in social theory and in the social sciences. Explorations of the role of freedom as a way to accept and often push for deregularization, flexibilization of labor, and precarity - as well as the reduction of civil and political rights - in the contemporary world have been numerous (Clarke 2005; Peters 2001; Rose 1999; Roberts 2010). These analyses, however, have largely revolved around two established arguments. ${ }^{5}$

The first, derived from Karl Marx's early writings, poses freedom as a toll of exploitation that displaces structural oppressive forces into the realm of individual decisions. As Marx $(1975,232)$ said in his exploration of the introduction of constitutional rights to liberty, "man was not freed from religion, he received religious freedom. He was not freed from property; he received freedom to own property. He was not freed from the egoism of business; he received freedom to engage in business." In the development of this line of thought, freedom becomes a hook that drags people into a false sense of empowerment while interpellating them into accepting and participating in contemporary capitalism or similarly oppressive projects (Althusser 1984; Santoro 2003; Žižek 1989). When applied to the drivers, this reading would see itsaraphäp operating as a mechanism through which they are not freed from their exploitation but rather given the freedom to exploit themselves by becoming their own bosses - entrepreneurial subjects who accept unstable and unsecure employment.

The second explanation, deriving from Michel Foucault's early writings on disciplinary apparatuses but largely ignoring his later explorations of ethics and techniques of the self, sees freedom as an apparatus that operates by creating its own subjects, "free individuals [who] become governable . . . as normal subjects" (Rose 1999, 76). In this view, most notably expressed in the work of Nikolas Rose, the ethics of freedom has come to provide the ground for our conceptions of how we should be ruled, how our practices of everyday life should be organized, how we should understand ourselves and our predicament - in other 
words, for our conduct of conduct. In this sense, Rose $(1999,87)$ argues, "modern individuals are not merely 'free to choose,' but obliged to be free, to understand and enact their lives in terms of choice."

Both of these approaches, while invaluable in positioning subjects in relation to capitalism, disciplinary apparatuses, and discursive imaginaries, miss the aspirational, affective, and personal dimensions of adopting freedom as an organizing principle that sustains conscious decisions to accept new forms of precarity, or stubborn refusals to do so. These explanations, in short, miss one basic question, namely: why do people accept and at times resist both this hegemonic discourse and its material consequences? The vocabularies of receiving freedom or being obliged to be free reduce the mechanisms of consent to brainwashing-false consciousness - or brain-shaping under the rubric of subject formation. ${ }^{6}$ In so doing, these approaches present passive subjects and dismiss their ability to understand the paradoxical nature of the political-economic and hegemonic processes, while also deciding to take part in them. ${ }^{7}$

This reduction, I argue, has largely derived from an analytic mistake, one that anthropology is particularly well suited to reveal and correct. Both analyses implicitly compare, and ultimately conflate, whichever local and contextual use of freedom they encounter in the real world with an abstract, absolute, and universal conception of Freedom — with a capital $f$ - as something obtained and not given or obliged to exercise. As a result, they always find the former lacking when compared with the latter, and cast passive subjects to explain and justify the gap between the two. In other words, both arguments ignore the core lesson of anthropology: context matters.

Nonetheless, while our discipline would seem to have a lot to contribute to this debate, it "has [historically] had strikingly little to say [about freedom]" (Laidlaw 2002, 311). Partly, this results from the fact that anthropologists have been as guilty as other social scientists of turning their attention-however critical - to Freedom with a capital $f$. As a discipline, we have pointed out its analytical shortcomings and unmasked its universalist, normative, and elitist nature (Bidney 1963; Mahmood 2005); we have revealed its grounding in Protestant and Western modernity (Keane 2007; Asad 2003) and its centrality to colonial and postcolonial governance (van der Veer 2001; Viswanathan 1998). In the process, however, we have too often turned our attention away from what I call freedom with a small $\mathrm{f}$, away from the contextual understandings of freedom that we encounter in our ethnographic engagements. These freedoms are not predicated on a metaphysical and ahistorical ideal, but always develop against a local experience of unfreedom 
and are therefore much more entangled in the complexity of people's experiences and political-economic transformations.

Recently, under the rubric of the anthropology of ethics, a number of authors have argued for a limited, qualified, and restricted understanding of freedom (Fassin 2014; Faubion 2011; Laidlaw 2013). Building on the late Foucault's explorations of freedom as a necessary condition of ethical practice (Foucault 1997, 283; 1984c, 245), rather than on his analysis of disciplinary power, they have pointed out that degrees of freedom - understood as the capacity to exercise choice and pursue alternatives - are always situated in an existing field of power relations and have called for an investigation of "how freedom is exercised in different social contexts and cultural traditions" (Laidlaw 2002, 311). While resonating with my own argument, their engagements have largely remained at the analytical level. As a result, they have stopped short of exploring local conceptions of freedom ethnographically and revealing how they operate as systems of value, objects of reflection, and compasses that orient people's lives, ${ }^{8}$ not just in relation to local moral worlds (Kleinman and Kleinman 1996) but also to political-economic restructurings. In this sense, our disciplinary engagements with freedom have yet fully to live up to our epistemological strengths, those of considering our informants as themselves social theorists and adopting their contextual use of freedom to recalibrate our own social theories, rather than the other way round. In this article, I propose to do just that.

In the traditional ethnographic manner I take the drivers' claims to 'itsaraphāp seriously ${ }^{9}$ — not as a product of brainwashing or brain-shaping - and ask: What do these migrants mean by freedom? Why have they decided to leave formal jobs in factories for the supposedly free life of job insecurity? How does this claim relate to changes in political-economic relations since the 1997 crisis? Finally, what can we learn about contemporary capitalism in and beyond Thailand by exploring how the 'itsaraphāp simultaneously operates as an emancipatory and an oppressive construct?

\section{TALES OF FREED MEN}

Adun was born in a small village in the northeastern province of Udon Thani, some fifty miles from the Laotian border. He arrived in Bangkok in 1979, at the age of fifteen. Adun spent his first month in the city walking to his job in a small shoe shop. As soon as he saved up a few hundred baht, he went back to the village, homesick. Desires for a stable income and a different life, however, quickly brought him back to Bangkok. He worked in jewelry-polishing, construc- 
tion, and furniture-making, only to land by the mid-1990s in a small chemical factory. In the seasonal trips back to his village, Adun got married, had children, but never moved his family to Bangkok, because of the high material and emotional costs of raising his kids away from land, family, and the village school.

After a few years in Bangkok, Adun got to know a group of motorcycle taxi drivers from his province who operated close to his factory. Saving up a little money, he bought a battered motorcycle and started to drive after his work hours. It was not until 1998, when he lost his job as a result of the financial crisis, that Adun turned his after-hours job into a full-time occupation. After the crisis and years of economic stagnation, the new job allowed him a renewed freedom. He had no boss to order him around and the opportunity to go back home whenever he wanted, without having to ask anyone or lose face with a refusal. On these trips Adun, like many other drivers, was able to reclaim what he saw as his central role as a man in the economic and social life of his family and village, a role that he had lost during his years working in a factory.

Adun was outspoken about the importance of itsaraphāp to his personal choices. Sitting at his street corner, he told me: "My family and I are happy with this job. It is a free life. You can come and go from home anytime. You can get money fast, every day, without waiting for the salary. I have "itsaraphāp." "What is this 'itsaraphap?" I asked. Adun responded:

I can go home whenever I want. I don't have to take leave. Don't have to ask anyone. I don't have to come to work. I can remain home if I get sick or get drunk. If I earn enough money for the day and I want to go home to sleep, I can do that. This is 'itsaraphap. I used to work for a company, I went home often and I was never promoted. I have to go back home to the village regularly: my family is there, my farm is there. . .. I like my job because it is a free job. They offered to take me back in the company I used to work for, but that job in Bangkok is bad for a countryman like me. The boss always looks down on you, always orders you around, always insults you. The last place I worked, the boss's son kept insulting me, shouting at me: a twenty-year-old kid with no experience, just out of university. I could not accept that. So I am happy now; I am my own boss.

The idea of being one's own boss also kept Boon, another driver, in this profession, even though his life was less connected to the village in which he grew up. Boon moved to Bangkok from an uncharacteristically prosperous cluster of villages in northeastern Thailand. The area was selected in the 1990s for a pilot 
agricultural project to expand rubber farming beyond southern Thailand, where the bulk of its production took place. The results were, at least at the time of my research, remarkable. ${ }^{10}$ Each house had a pickup truck parked outside, roads were paved, the village school had a computer room, and a steady flow of returnees from Bangkok were joining the remunerative agricultural business. Boon was not, and would not be, among them.

Boon had moved to Bangkok in the 1980s looking, like thousands of other migrants from the impoverished northeast, for a good income, entertainment and adventure (pai thieo), and a modern life (chīwitbapthansamai) (Pattana 2006; Walker 2012; Mills 1997). After the plantations were introduced in his village, the modern technology of rubber production cut him off from home. During the family's first harvest, Boon discovered he was allergic to the chemicals used to transform latex into rubber, and from then on he visited only occasionally and accepted he could never work there. Similarly to Adun's, Boon's life in Bangkok was a sequence of low-paid jobs, some of them decent and some remembered with contempt, which came to an abrupt end with the 1997 crisis, when he was laid off. Unable to go back to his village, Boon bought a bike and became a driver.

Income was not a central concern to Boon, as a share of the family farm ensured him a regular cash flow. Nor, it seemed, was personal safety, as testified by his upper body, scarred by the signs of multiple road accidents, which shattered his forearm bones and left his right arm slightly bent, unable to extend fully. But Boon was a prideful man, and the "itsaraphäp offered by his new occupation proved central to keeping him in this line of business. "I never liked to follow orders," he told me, sitting on his bike, a cigarette hanging from his mouth. "I came to Bangkok to have my own life, and I found myself sitting at a table, fixing electric components or sewing bags. Now I have a free life ['ächipp 'itsara]; I come to work whenever I want, I leave whenever I need.”

"But you always stay until night," I responded. "I see you here every morning until sundown; you work more than in a factory."

"Yes, maybe," he interrupted, "but it's my own decision."

Similar exchanges were repeated, with minimal variations, hundreds of times during the course of my research. Through the idiom of itsaraphap, the drivers claimed their human and economic independence from the crushing machine of mass production and its organization of labor, as well as - at least for drivers who traveled back home - a renewed form of participation in the economic and emotional life of their villages. If the language of adventure and modernity had directed internal migration and permanence into the industrial and service economy, as 
Boon mentioned and as Mary Beth Mills's (1999) work among female migrants has analyzed in detail, by the time of my fieldwork in the early 2010s, the idiom of 'itsaraphäp had taken over, at least among workers who were pushed off of the factory floor and joined the booming flexible service economy. ${ }^{11}$

To understand the role of 'itsaraphāp in the drivers' professional decisions following the 1997 crisis, therefore, it is fundamental to dissect how the word is used in Thai, as well as the meaning it acquired for workers like Adun and Boon after the crash. Composed by 'itsara (to be free, independent) and phāp (vision, image), the word 'itsaraphap started to be used at the end of the nineteenth century in relation to the colonial encounter. The word was interchangeable with sovereignty and referred to collective entities, dominating the debates over the abolition of slavery in the country in 1905 and the Siamese risks of colonial subjugation. It was only between the 1920s and the 1930s that 'itsaraphap assumed its individual connotations, as Western-educated Siamese elites diffused the idea of individual free will against the authority of the sovereign, initiating a debate that would bring the end of absolute monarchy in 1932 (Aphornsuvan 1998). Thus understood, the word acquired its contemporary use and carried strong individual connotations of self-reliance and sovereignty over oneself.

Adun's and Boon's depiction of 'itsaraphāp retains this meaning, and does so in a double sense. On the one hand, they conceive of it as a form of autonomy from the factory discipline of labor that infantilized, dehumanized, and forced them to subordinate their working hours and participation in family and agricultural life to the whims of their bosses. On the other hand, they talk about the freedom to go back home whenever they want, to organize their own schedules, and ultimately to be their "own bosses" and make their "own decisions." This duality echoes the British philosopher Isaiah Berlin's (1969) double understanding of freedom as positive and negative. ${ }^{12}$ It is in this double territory of positive freedom (as freedom to) and negative freedom (freedom from) that the drivers sustain their commitment to their occupation. To begin to understand why the itsaraphap of precarious employment becomes attractive to them, therefore, we need to investigate not only the drivers' everyday life and aspirations but also the politicaleconomic conditions under which this precarious, insecure, and unstable job has become a synonym of freedom.

Adun and Boon, like many other drivers, moved to Bangkok from villages where occasional and sporadic wage labor complemented regular yet seasonal work in the fields. Their activities in the village - whether as wage or agricultural labor-were organized according to social hierarchies and relations that went 
beyond the factory-floor division of labor. Back home, age, family relations, expertise, and status provided a hierarchy in and beyond labor processes, which appeared to them more transparent and navigable, compared to the division of labor in the factories where they landed once in the city. This does not mean that the village offered some mythological and precapitalist space of free and equitable production - much as the drivers, as well as the larger dominant discourses in Thai society, often nostalgically seem to imply (Dayley 2011). Nor does it mean that economic class, bureaucratic titles, and social capital played no role in the village. Rather, and more concretely, all these social relations and interactions in the village preceded and extended beyond the labor transaction. As a result, disciplining labor could not take the form of direct and frontal dismissal, attack, or scolding, or at least not without the risk of jeopardizing social standing, for both the employer and the employee.

Very different is the matter in the anonymity of urban industrial production. Here both the actors involved have nothing at stake in the preservation of a good relationship with any specific worker or employer beyond keeping their working arrangement. To use Marxist terms, labor in the city has been abstracted. While this configuration offers a respite from the expectations of the localized and intimate social hierarchies that orient labor in the village, it also creates a space in which disdain, scorn, and open derision-forms of engagement considered extremely offensive in Thailand (Persons 2016) — color the relations between workers and employers. To make things worse for rural migrants, a deeply rooted urban bias against them often orients these already uneven interactions in urban factories. In particular, the discourses of the backward and stupid villager (chāo bān) provide a framework inside which the relation between urban employers and rural employees is understood and experienced. A failure to adjust to the factory's organization of labor is accepted, justified, or exacerbated through this lens by migrant workers and urban employers alike. This failure, when it occurs, is often framed in a dehumanizing language, which compares migrants to water buffalos (khwāi), quintessentially stubborn and stupid animals - another unacceptable offense.

In this context, Adun's and Boon's occupation as motorcycle taxi drivers, even if taken up as a result of post-crisis layoffs, offers a step away from the system of control and discrimination experienced on the factory floor. In their words, being a motorcycle taxi driver provides itsaraphāp from such forms of discipline and stigma, but it also configures a positive freedom or itsaraphāp to. Adun views positive freedom as entailing two levels: first, the freedom to decide 
if and when to go to work, and therefore to claim ownership over his own life, income, and daily rhythms; second, the freedom to leave the city and go back to his village, where his family resides and where their fields are, whenever he wants or needs to. Both of these forms of freedom are presented as emancipatory forces that enable him to live a less alienated life. In the first case, it amounts to the exercise of a refusal of alienated labor on the factory floor and a reclaiming of control over his own body and time; in the second, to the practical realization of the demand to participate in family and village life and to pursue alternatives threatened by regional migration and the urban organization of labor (Rigg et al. 2008).

'Itsaraphāp, as Boon and Adun conceive it, operates on a personal level as a construct that helps them make sense of their labor trajectories, as well as claim pride in and agency over their lives. Its role, however, does not stop at the personal and experiential level. As William Roseberry (1994, 361) has argued, similar hegemonic constructs generate "not a shared ideology but a common material and meaningful framework for living through, talking about, and acting upon social orders characterized by domination." In other words, 'Itsaraphāp not only becomes a framework for making sense of their new lives as an experience of emancipation but also provides a framework for making do with new forms of domination and the increasingly precarious lives generated by the post-crisis restructuring of Thai capitalism. 'Itsaraphap, therefore, not only operates on the personal level I have so far analyzed but also functions at a collective and structural one, as a way to push an increasing number of unnecessary industrial laborers toward more precarious forms of employment, such as driving motorcycle taxis. Focusing our attention only on the first level, therefore, would mean seeing these individual stories as plots of land but failing to grasp the larger landscape in which they are located and by which they are shaped. Until now I have focused only on Adun's and Boon's plots and explored the role of 'itsaraphāp in organizing them. In the following sections, I place them into the larger landscape of shifting relations between labor and capital in Thailand since 1997, away from industrial production, unionized labor, and collective bargaining toward flexible accumulation, entrepreneurship, and precarity (Sauwalak 2002; Hewison and Tularak 2013).

\section{FREEDOM AS POST-FORDIST HEGEMONY}

In the late 1980s and early 1990s, Southeast Asian economies experienced a period of unprecedented growth, led by a massive influx of foreign capital and a realignment of national economies toward export-oriented industrialization. 
Between 1986 and 1996, Thailand's GDP grew faster than in any other nation of the world, 9.5 percent per year. This unprecedented growth came to a halt in 1997.

On May 14 and 15, 1997, the Thai baht was hit by speculative attacks, driven by the ease with which capital moved in and out of the country and the increasing instability of the national economy. This was the spark that ignited the Asian financial crisis. In a few days, the Thai currency lost more than half of its value. Suddenly most Thai companies that had borrowed in foreign currencies saw their debt burden doubled and went into bankruptcy, provoking an estimated two million layoffs in finance, real estate, industry, and construction (Pasuk and Baker 1998). Migrant workers reacted either by returning to agricultural land, which had traditionally offered a security net in times of economic recession, or by entering the swelling informal economy. The growth in the ranks of motorcycle taxis after the crisis was stark, even at a time when the city was getting smaller because of the departures of many laid-off workers. In 1994, Bangkok was home to an estimated 37,500 drivers. By 2003, their numbers had expanded almost threefold, to $109,056 .^{13}$

More broadly, Thai capital shifted toward flexible accumulation, a regime that pushed "flexibility with respect to labor processes, labor markets, products, and patterns of consumption, . . . characterized by the emergence of entirely new sectors of production, new ways of providing financial and business services, new markets, and, above all, greatly intensified rates of commercial, technological and organizational innovation" (Harvey 1990, 1). Following the crisis, the Thai economy began to move away from the centrality of industrial production, collective bargaining, and the support of workers' buying power through rising salaries rather than the welfare provisions that had characterized Thai Fordism. As a result, it shifted toward a post-Fordist configuration dominated by flexible labor based on risk-taking entrepreneurialism, easier access to debt, and more precarious lives, even if in the context of an expansion of state-run welfare policies. ${ }^{14}$ For millions of workers, this meant the reduction of fixed contracts and the expansion of occupations not protected by any form of labor rights or collective bargaining (Warr 2005; Pasuk and Baker 2008).

'Itsaraphāp played a central role in providing a "meaningful framework for living through, talking about, and acting upon" (Roseberry 1994, 361) this flexibilization of labor, self-employment, and its growing insecurity. It made precarity not only acceptable and bearable to workers, including motorcycle taxi drivers, but in fact desirable. This does not mean that 'itsaraphāp operated solely as a bait 
into post-Fordist capitalism. Rather, for the drivers and millions of other workers, freedom supported their emancipation from the factory discipline of labor and its limited mobility, but also framed new oppressive structures. This occurred not despite the real advantages that the new configuration offered, but precisely because of them. The framework of itsaraphapp became dominant not because it duped these workers or obliged them to conform to it, but because it connected the requirements of post-Fordist restructuring with the everyday desires and aspirations of its increasingly precarious workers, who wanted to define themselves in opposition to the factory discipline of labor they had experienced before the crisis. In this sense, it is always — as Raymond Williams (1977) has stressed — an alignment between people's agency, desires, previous experiences, and existing possibilities that pulls them into hegemonic consent, and not passive understandings of false consciousness or subjugation.

This dynamic is by no means peculiar to motorcycle taxi drivers or to Thailand, even though its specific configurations are. Many have accepted selfemployment and flexible labor as a recovered independence from the tyranny and dullness of fixed-schedule jobs, only to find themselves outside the protective net of collective bargaining and permanent jobs. Have they acquired renewed freedom by becoming their own bosses and being able to mold their working hours to family arrangements or personal preferences? Most definitely. Have they, at the same time, accepted a retreat of both government and employers from providing basic services and securities? Absolutely. How is this paradox possible? And, more to the point, does this acceptance mean they were passively given freedom or obliged to be free?

The work of Antonio Gramsci helps us to answer these questions and to understand the daunting tensions they suggest. In his prison writings on Italian history, Gramsci (1971) clarifies how hegemony and control sustain each other and how an emancipating personal discourse — such as that of 'itsaraphāp as voiced by Adun and Boon — can also sustain an oppressive form of hegemony. This is as much the case with fascism, the implicit reference of Gramsci's analysis, as it is with post-Fordism in Thailand. The Italian workers who supported Mussolini, to whom Gramsci hints between the lines of his heavily controlled prison notebooks, were not gullible passive agents, tricked into false consciousness. Neither, for their part, are the drivers who willingly accept reduced job security and limited social services. Rather, as Gavin Smith (2004, 99-100) has pointed out, "the epistemological bedrock of the ideas contained in the notion of hegemony rejects the possibility of the social person as object, passive recipient, or cultural dupe, 
just as it minimizes the moments when consciousness can be false." Starting from this bedrock, Gramsci $(1971,12)$ elucidates how control over social groups takes two forms: domination and hegemony. While the first is obtained through the coercive organs of the state, the second entails an "intellectual and moral leadership" exercised through civil society — a composition of educational, religious, and associational institutions. This second form of submission operates through the "spontaneous consent given by the great masses of the population to the general direction imposed on social life by the dominant fundamental group, consent 'historically' caused by the prestige (and therefore by the trust) accruing to the dominant group." While until now I have shown what this spontaneous consent is based on among motorcycle taxi drivers in Thailand, I will now turn toward an analysis of how the hegemony of itsaraphäp emerged after the 1997 crisis and, to go back to the question I started with, why people accepted it.

\section{A BRIEF HISTORY OF POST-FORDIST 'ITSARAPH $\bar{A} P$}

In the first few years after the 1997 economic collapse, Thailand followed the International Monetary Fund's (IMF) gospel of structural readjustment. The country opened to foreign investors, cut government spending - in particular, spending on social services - and deregulated its labor and financial markets. The plan ensured that foreign lenders would be repaid, but it proved disastrous for the country and its economic sovereignty. The national GDP fell by 7.9 percent in 1997, 12.3 percent in 1998, and 7 percent in the first half of 1999. By 2000, three years after the crisis, Thailand was still in recession, while Malaysia, ignoring the IMF's suggestions, was in full recovery (Stiglitz 2002). In Thailand, the crisis became known as wikrit IMF (IMF crisis) and was understood to have neoliberal policies as its source. The country, therefore, called for solutions that kept their distance from a classic neoliberal agenda. Thaksin Shinawatra - a billionaire who made his money in telecommunications — was elected prime minister in 2001 and pushed for a significant expansion of the state's role in promoting economic growth and managing its social consequences, against the IMF's prescriptions.

At the core of Thaksin's vision was a post-Fordist flexibilization of labor, the application of the logic of management to public administration, and a redefining of citizens as entrepreneurs. This meant providing them with access to credit, both as a way of freeing up their economic activities and supporting their consumption, as well as pushing for an expansion of state interventions in the national economy — not the shrinking theorized by the IMF. His recipe revolved around five main policies that were implemented during the first six months of 
his premiership: a rural debt moratorium, a village and urban community revolving fund, the creation of the People's Bank, the One Tambon (district), One Product scheme, and universal health-care coverage. ${ }^{15}$ Overall, this system was aimed at fostering universal participation in capitalism by making small businesses and low-income people into free entrepreneurs - a classic neoliberal projectbut it did so by expanding welfare provisions to protect these entrepreneurs from unexpected difficulties, in particular health expenses and outstanding debts.

The idea of turning workers into free entrepreneurs became the new organizing principle of contemporary Thailand, a set of material and symbolic provisions that emerged under Thaksin's premiership but survived its deposition in 2006 by a military coup. Even though military officers, royalist forces, and fiscal conservatives have attempted in the past decade to shift this approach, time and again electoral masses have thrown their support behind it. The aim of these provisions, in Thaksin's words, was to create "a new class of entrepreneurs who could marry local skills with international technology and hence move up the value chain" (Pasuk and Baker 2002, 3). Among these new entrepreneurs, Thaksin liked to repeat, were motorcycle taxi drivers: a new free labor force that decided to leave behind the shackles of dependent occupation to enter the brand-new world of self-employment and entrepreneurship.

This "liberal reason"_ as Michel Foucault (2008, 69) has pointed out"must produce freedom, but this very act entails the establishment of limitations, controls, forms of coercion, and obligations relying on threats." Thailand was no exception. First, by becoming their own bosses, the drivers also became their own exploiters and, as both entrepreneurs and workers, they morphed exploitation into forms of sacrifice to build their own capital, investing in themselves. Second, as Thaksin ostensibly freed entrepreneurial forces from the binds of the Fordist discipline of labor, he also proceeded to control their flows, effectively posing limits on their free entrepreneurship. In 2003, two years into his first premiership, Thaksin registered, archived, and controlled the drivers' operations. Like many state institutions that advance deregulation and free markets as they tighten control on their borders and strengthen their intelligence apparatus to spy on their own citizens, the Thai government pushed its workers toward free and flexible forms of labour while registering and making them more visible and controllable.

The registration of motorcycle taxis constituted a central piece in a larger government campaign, known as the "war on dark influence" ('itthiphon mü't). This formulation pointed to a variety of interventions that attempted to bring 
different sectors of the illegal economy_from logging to prostitution, from underground lotto to motorcycle taxi operations - under the administrative and economic control of the government, include them in the formal market, and provide assistance to its entrepreneurs. More broadly, this campaign represented a litmus test for the new approach to low-income economic actors proposed by Thaksin. In his vision, their entrepreneurship had been constrained by a lack of state services and access to credit for too long. It was now time to free their capitalist acumen, but only inside the control of a strong state able to see, control, and ultimately tax. ${ }^{16}$ Motorcycle taxis became the showcases of this new approach. On May 20, 2003, Thaksin initiated a registration of operating drivers with their district offices, and by late August, district offices in Bangkok distributed new vests to the drivers, which would operate as personal licenses and, at least in theory, as collateral. Now the drivers were free entrepreneurs, but only insofar as they were framed by a new system of registration and control, allowing the state to monitor their location, take away their licenses in the case of accidents or drunk driving, and keep their numbers stable.

Boon was very much aware of this paradox and still refuses to this day to put on one of the government's official vests and register with the local administration. "I chose this job because it gave me 'itsaraphap, and I am not going to give them my name and location to be under government control," he told me. Boon's adamant reaction, however, was just a drop in the sea. Most of the drivers accepted the registration as recognition of their roles as significant actors in the life of the city, stakeholders in the Thai state, as well as as free entrepreneurs, rather than as good-for-nothing, lazy country bumpkins.

On the whole, the emergent discourse of free entrepreneurship, the drivers' participation in it, the establishment of new systems of control, and the precaritization of their lives reveals the complex role of 'itsaraphap in post-Fordist Thailand as both personally emancipating and structurally oppressive. On the one hand, the vision of drivers as entrepreneurs depoliticized exploitation, job insecurity, and social inequality by reframing them as individual successes or failures based on effective decisions, rather than on structural relations. On the other hand, it provided the drivers with recognition, pride, and a sense of dignity in their decision to escape the industrial discipline of labor and become their own bosses, as voiced by Adun and Boon. 


\section{CONCLUSION}

The analysis of the drivers' emancipatory experiences of 'itsaraphāp and its relation to oppressive capitalist restructuring in Thailand since the 1997 crisis has brought us to two central paradoxes. First, the paradox of using freedom to motivate the acceptance of precarious labor arrangements. Second, the paradox of unleashing free entrepreneurship only to enforce more stringent state control. These two paradoxes are by no means exclusive to motorcycle taxi drivers in Bangkok or even to migrant workers in Thailand. They, in fact, echo existing ethnographic engagements with entrepreneurship, precarity, and late capitalism globally (Ferguson 2006, 2010; Elyachar 2012; Li 2007; Ong 2006; Slocum 2006; Comaroff and Comaroff 2001; Muehlebach 2012). These echoes are deliberate and, while they cannot be further explored in the context of this article, provide a backdrop and an implicit comparison to my argument. ${ }^{17}$

Even though they take specific forms in different contexts, these apparent contradictions largely revolve around allowing free flows and activities only insofar as they can be transformed into legible aggregate flows, and externalizing social relations - such as exploitation or job security - to individual entrepreneurship by fostering individual freedom. These paradoxes lie at the core of the question that directed my investigation, namely, why people consent to their roles within hegemonic systems - be they nation-states, dictatorships, or capitalist structures. As I have argued, orthodox Marxism solved these paradoxes through the idea of false consciousness, and certain strains of poststructuralism through an analysis of the roles of discipline and subjugation in exercising power. Both attempt to give a general answer to a question that, as I have tried to show, requires contextual analysis and responses. Once we abandon this generality, we can provide an answer that does not entail an account of people being duped. Moreover, we reveal these paradoxes not as contradictions that challenge capitalism but as generative forces that, on the contrary, sustain this system by offering significant emancipatory possibilities while framing new forms of oppression. In this sense, capitalism - here in its specific post-Fordist forms it has taken in contemporary Thailand - proves to operate, like electricity, by creating opposite magnetic poles (freedom and control; emancipation and oppression) and harnessing energy from their tension, rather than crumbling under the resulting contradictions. ${ }^{18}$ The paradoxes I have pointed out constitute two of the many ways in which these tensions are created in contemporary Thailand.

Let me address the second paradox, that between the growth of free enterprise and tighter control over its activities — which is the contextual declension 
of a larger paradox between free markets and the expansion of state control and repression. Presenting states and markets as in opposition to one another has been one of the main myths told by apologists of neoliberalism, one taken at face value by many scholars (e.g., Ong 2006; Boyer and Drache 1996). ${ }^{19}$ However, as Karl Polanyi (1944) has argued and the 2008 bailouts revealed most strikingly, markets are not architectonic; they need states to create, preserve, and manage them. As a consequence, "under capitalism the impetus to increase productivity generates a tension having to do with the enhancement of the creative potential of people and its harnessing with an enclosure that captures the value that results and directs it back toward capital" (Smith 2011, 24). In other words, free markets need tight state interventions to direct flows, without which their fruits are of no use. This was certainly true in the case of motorcycle taxis in Thailand, where the new entrepreneurship of the drivers needed state control and visibility to flourish and be aggregated and harnessed into significant economic forces.

The same generative tension lies at the core of the two uses of 'itsaraphāp as workers' emancipation from labor discipline and as oppressive justification for labor restructuring. At first glance, the contradiction seems irreconcilable. This, however, holds true only if we understand Freedom with a capital $f$, a universal and absolute category that stands in opposition to control, as its archenemy and not its ally. In this view, any form of freedom that does not achieve decontextualized liberation remains incomplete and does not deserve the name. This vision limits our ability to understand the drivers' attitudes, as well as those of millions of workers around the world, basically pronouncing them unable to understand their own situations. On the contrary, as Wendy Brown (1995, 6) has argued, "freedom is neither a philosophical absolute nor a tangible entity but a relational and contextual practice that takes shape in opposition to whatever is locally and ideologically conceived as un-freedom." For the drivers, the Fordist disciplining of labor was, around the time of the crisis, the epitome of unfreedom, an oppressive system that limited their mobility, controlled their time, and broke their spirit. Post-Fordist itsaraphäp offered a way out of that, attractive even as it constructed new limitations around them.

If we abandon the abstract idea of Freedom, the answer to the question with which I began this article — why do people accept being part of hegemonic systems or being interpellated in them-is quite simple. It is because they understand freedom, emancipation, and oppression as contextual practices and processes. As a result, the personal freedoms obtained by moving toward self-employment are not illusory and do make a difference in the drivers' lives, freeing them from 
degrading labor conditions on the factory floor and allowing them to work in the city without cutting themselves off from life in their villages. Being their own bosses and being able to participate in agricultural life, therefore, constitutes emancipation, at least from the Fordist disciplining of labor. At the same time, this new freedom also frames new forms of oppression — of which the drivers are both aware and against which they often mobilize (Sopranzetti 2014) - that keep them in a precarious occupation under increasing state control. In this sense, the drivers, like the rest of us, always navigate between double binds, limited by our own frameworks but also freed by them, claiming a freedom that is both an emancipatory demand for activities outside the dictates of our present oppression and the raw material of a new one. Freedom is emancipation and oppression all the way down, but each specific configuration frames the reality of our social life, offers a horizon of emancipation from the previous level, and shapes the oppression of the present one.

\begin{abstract}
Based on ethnographic research conducted between 2009 and 2014, this article examines the discourse of freedom ('itsaraphāp) among motorcycle taxi drivers in Bangkok and the practices, both emancipatory and oppressive, that it supports and makes possible. I explore its central role in their self-construction as successful migrants, entrepreneurial subjects, and autonomous urban dwellers, as well as its relations to capitalist restructuring and precarity in post-crisis Thailand. I show how freedom offers a way for precarious workers - such as the drivers - to consciously make sense of and make do with political-economic, social, and conceptual shifts taking place around them. In this sense, this article explores the construction of consent in contemporary Thailand without falling in the trap of assigning false consciousness to the drivers or of framing them as subjugated subjects. Rather, I locate the effectiveness of 'itsaraphāp discourse precisely in its ability to connect preexisting forms of exploitation, personal desires, and aspirations with a restructuring of the relations between capital and labor in contemporary Bangkok. [freedom; capitalism; entrepreneurialism; Thailand]
\end{abstract}

\title{
NOTES
}

Acknowledgments I thank Anand Vaidya, Eli Elinoff, Lizzie Presser, David Gellner and Michael Herzfeld for reading multiple versions of this article and making it better at each turn. The three anonymous reviewers contributed greatly to the development of this piece, which could not exist in the present form without the careful assistance and engagement of James Faubion.

1. These numbers are an estimate, generated in collaboration with the Association of Motorcycle Taxis of Thailand.

2. This article follows the American Library Association/Library of Congress (ALA-LC) 
system of Romanization, which uses diacritics to mark length of vowels rather than tones, leaving tones unmarked.

3. Anthropological engagements with precarity have mostly emerged in the context of retreating welfare states (Molé 2013; Allison 2012; Muehlebach 2013). As a result, their definition of precarity has taken a specific form of precaritization - the retreat of welfare states - and expanded it to define much larger trends in contemporary capitalism (Kalleberg and Hewison 2013; Lee and Kofman 2012). While some scholars have argued for the use of the concept exclusively in these contexts (Neilson and Rossiter 2008), I take the opposite view and argue for its relevance to contemporary Thailand. The concept has been adopted recently by a few anthropologists of Thailand (Endo 2014; Johnson 2012), but without defining its meaning in a country in which the welfare state has been expanding in the past decades, rather than contracting. To exit this impasse, I here define precarity as an experience created by a variety of forms of unstable, flexible, unbounded, and individualized employment, one only marginally protected by social benefits, legal provisions, or collective bargaining. These include the informalization of labor, seasonal and temporary employment, homework, flex and temp work, subcontracting, freelancing, and self-employment. While this status emerges out of labor arrangements, the conditions they generate go well beyond the sphere of employment and extend their characteristics of instability, flexibility, and individualization to subjectivities, social relations, and imaginaries of the future.

4. Here, Fordism describes an alignment between the form of the organization of labor based on mass-serialized production and a compromise between labor and capitalpredicated on transforming workers into consumers through salaries, which dominated Thai capitalism from the 1980s to 1997. In Euro-America, this alignment is often conflated with Keynesian anticyclical welfare programs that emerged there-but not in Thailand - in relation to Fordism. Acknowledging the different histories in relation to social welfare and the state's economic planning, I define the contemporary shift in Thailand as post-Fordist and not neoliberal. The neoliberal doctrine emerged - in the words of its founding fathers in the Mont Pèlerin society - to find a middle path between Keynesian state planning and Adam Smith's liberal market (Burgin 2012). As a dominant political project - one that advocated for market liberalization, cuts in labor rights, reduction to income taxes for the wealthy, and the retreat of the welfare stateneoliberalism emerged in the 1980s under the governments of Ronald Reagan and Margaret Thatcher. Ignoring its contextual history, the label of neoliberalism has been projected onto the rest of the world, often with little analytical rigor (see Ferguson 2010). In this reading, any restructuring of relations of production, labor practices, and national policies is seen as a sign of neoliberalism, even in countries like Thailand, where the state has been expanding its planning presence in the economy and introducing unprecedented welfare schemes. Refusing this oversimplification, I prefer to focus on post-Fordism, a system that does not configure specific relations between states and capital, or to the retreat of the welfare state, but rather reorganizes the relations between capital and labor away from mass-serialized production and raising workers' buying power through salaries, as has been happening in Thailand since 2001, even as the welfare state has expanded.

5. These are obviously ideal types of existing arguments, presented in their most extreme versions, which may not be fully endorsed by most, or even any, of their proponents. Exaggerating their characteristics, however, helps us to reveal the existing spectrum of explanations and, in so doing, to shed light on underexplored alternative routes.

6. A significant body of literature that questions these two views by focusing on local desires among postpeasants is emerging in Southeast Asia, specifically in relation to shifting logics of capital (Walker 2012; Sopranzetti 2012; High 2014; Li 2014). The present article is an attempt to expand these approaches to a study of freedom in Thailand.

7. I am here referring to a specific - and possibly incorrect - understanding of subject formation and freedom. As James Faubion has shown, Foucault himself pointed out the 
fallacious nature of this passive understanding of subject formation in the later part of his life. For Foucault, "ethical practice proceeds after all in the middle voice, actively and passively often at one and the same time" (Faubion 2011, 50). In this sense, Foucault (1997, 1984a, 1984b), while acknowledging his role in allowing this misunderstanding to emerge, showed how subjects are neither unfree to participate in their formation nor fully at liberty to invent their own techniques of the self.

8. For exceptions, see Riesman 1977, Slocum 2006, and Englund 2006.

9. In doing this, I make no claims of moving away from the realm of epistemology and, somehow, elevating myself to a study of ontologies. I am dealing with how people make sense of and make do with realities around them, not with a hard-to-defend claim of gaining access to some ontological dimension of radical alterity (see Graeber 2015).

10. The global price of rubber has since plummeted.

11. Maureen Hickey $(2010,146)$ has pointed out the emergence of the discourse of itsara in her study of cab drivers in Bangkok and argued that after the crisis, the traditional Thai conception of 'itsara, "stressing free will and responsibility for one's actions, has been reworked to reflect the neoliberal ideals of the autonomous individual and rational economic actor." Despite her laudable attempt to connect conceptions of personal freedom with larger economic, social, and political restructurings, her reading - following an argument proposed by Nikolas Rose - concludes that freedom is reworked from an emancipating force to an oppressive one, one in which subjects are obliged to take part.

12. For an extensive analysis of the centrality of Berlin's liberal conception of freedom, see Laidlaw 2013.

13. These numbers come from unpublished data on motorcycles registered for public use, which I obtained from the Ministry of Land Transportation.

14. In my book manuscript, I analyze the characteristics of this expansion of the welfare state in detail (Sopranzetti, forthcoming). Suffice it to say here that welfare provisions established since 2003 were not Fordist/Keynesian anticyclical interventions aimed at supporting workers in their unproductive phases, but rather represented a Schumpeterian welfare state that supported already productive forces and fostered their entrepreneurialism.

15. The debt moratorium allowed farmers to postpone their repayments to the Bank for Agriculture and Agricultural Cooperatives, while the revolving fund for villages or urban communities provided cheap loans, promoted local community-building, and stimulated the entry of farmers and the urban poor into the capitalist economy. The People's Bank funded low-income people to invest in microbusinesses, while the One Tambon, One Product scheme provided government-led guidance to such microbusinesses. Under this policy, the state offered local districts technical support to choose a specific product or service typical of their area and develop its production and marketing, with the purpose of making it attractive to international markets. Finally, and most successfully, the universal health-care system, popularly known as the "thirty-baht scheme," provided lower-income citizens with affordable health assistance.

16. This idea was predicated on the theories of the Peruvian economist Hernando de Soto, which were introduced to Thaksin by President Bill Clinton.

17. In my forthcoming monograph (Sopranzetti, forthcoming), I explore more fully the role of these paradoxes in contemporary Thai capitalism.

18. However, most contemporary Marxists have failed to accept that the contradictions they rightfully describe, rather than weakening capital, have become its central strengths, allowing the system to constantly renew itself.

19. Aiwa Ong's $(2006,6)$ definition of neoliberalism offers a prime example of this analytical slippage. According to Ong, neoliberalism is "(a) a claim that the market is better than the state at distributing public resources and (b) a return to a primitive form of individualism: an individualism which is competitive; possessive; and construed often in terms of the doctrine of 'consumer sovereignty."' 


\section{REFERENCES}

Allison, Anne

2012 “Ordinary Refugees: Social Precarity and Soul in Twenty-First-Century Japan." Anthropological Quarterly 85, no. 2: 345-70. https://doi.org/10.1353/anq. 2012.0027.

Althusser, Louis

1984 Essays on Ideology. London: Verso.

Aphornsuvan, Thanet

1998 "Slavery and Modernity: Freedom in the Making of Modern Siam." In Asian Freedoms: The Idea of Freedom in East and Southeast Asia, edited by David Kelly and Anthony Reed, 161-82. New York: Cambridge University Press.

Asad, Talal

2003 Formations of the Secular: Christianity, Islam, Modernity. Stanford, Calif.: Stanford University Press.

Berlin, Isaiah

1969 Four Essays on Liberty. New York: Oxford University Press.

Bidney, David, ed.

1963 The Concept of Freedom in Anthropology. The Hague, Netherlands: Mouton.

Boyer, Robert, and Daniel Drache, eds.

1996 States against Markets: The Limits of Globalization. New York: Routledge.

Brown, Wendy

1995 States of Injury: Power and Freedom in Late Modernity. Princeton, N.J.: Princeton University Press.

Burgin, Angus

2012 The Great Persuasion: Reinventing Free Markets since the Depression. Cambridge, Mass. Harvard University Press.

Clarke, Simon

2005 "The Neoliberal Theory of Society." In Neoliberalism: A Critical Reader, edited by Alfredo Saad-Filho and Deborah Johnston, 50-59. Ann Arbor, Mich.: Pluto Press.

Comaroff, Jean, and John L. Comaroff, eds.

2001 Millennial Capitalism and the Culture of Neoliberalism. Durham, N.C: Duke University Press.

Dayley, Robert

2011 “Thailand's Agrarian Myth and Its Proponents." Journal of Asian and African Studies 46, no. 4: 342-60. https://doi.org/10.1177/0021909611400547.

Elyachar, Julia

2012 "Before (and After) Neoliberalism: Tacit Knowledge, Secrets of the Trade, and the Public Sector in Egypt.” Cultural Anthropology 27, no. 1: 76-96. https://

Endo, Tamaki doi.org/10.1111/j.1548-1360.2012.01127.x.

2014 Living with Risk: Precarity and Bangkok's Urban Poor. Singapore: National University of Singapore Press.

Englund, Harri

2006 Prisoners of Freedom: Human Rights and the African Poor. Berkeley: University of California Press.

Fassin, Didier

2014 "The Ethical Turn in Anthropology: Promises and Uncertainties." HAU: Journal

Faubion, James D.

of Ethnographic Theory 4, no. 1: 429-35. https://doi.org/10.14318/hau4.1.025.

2011 An Anthropology of Ethics. New York: Cambridge University Press.

Ferguson, James

2006 Global Shadows: Africa in the Neoliberal World Order. Durham, N.C.: Duke University Press. 
2010 “The Uses of Neoliberalism.” Antipode 41, S1: 166-84. https://doi.org/10. $1111 /$ j.1467-8330.2009.00721.x.

Foucault, Michel

1984a “On the Genealogy of Ethics: An Overview of Work in Progress." In The Foucault Reader, edited by Paul Rabinow, 340-72. New York: Pantheon. Originally published in 1982.

1984b "Politics and Ethics: An Interview." In The Foucault Reader, edited by Paul Rabinow, 373-80. New York: Pantheon.

1984c “Space, Knowledge, and Power." In The Foucault Reader, edited by Paul Rabinow, 239-56. New York: Pantheon. Originally published in 1982.

1997 "The Ethics of the Concern of the Self as a Practice of Freedom." In Ethics: Subjectivity and Truth, edited by Paul Rabinow, 281-302. New York: New Press. Originally published in 1984 .

2008 The Birth of Biopolitics: Lectures at the Collège de France, 1978-1979. Translated by Graham Burchell. New York: Palgrave Macmillan. Originally published in 2004.

Graeber, David

2015 "Radical Alterity is Just Another Way of Saying 'Reality': A Reply to Eduardo Viveiros de Castro." HAU: Journal of Ethnographic Theory 5, no. 2: 1-41. https://

Gramsci, Antonio doi.org/10.14318/hau5.2.003.

1971 Selections from the Prison Notebooks. Edited and translated by Quintin Hoare and Geoffrey Nowell Smith. New York: International Publishers.

Harvey, David

1990 The Condition of Postmodernity: An Enquiry into the Origins of Cultural Change. Malden, Mass.: Blackwell.

Hewison, Kevin, and Woradul Tularak

2013 "Thailand and Precarious Work: An Assessment." American Behavioral Scientist 57, no. 4: 444 -67. https://doi.org/10.1177/0002764212466244.

Hickey, Maureen Helen

2010 "Driving Globalization: Bangkok Taxi Drivers and the Restructuring of Work and Masculinity in Thailand." PhD dissertation, University of Washington.

High, Holly

2014 Fields of Desire: Poverty and Policy in Laos. Singapore: National University of Singapore Press.

Johnson, Andrew Alan

2012 "Naming Chaos: Accident, Precariousness, and the Spirits of Wildness in Urban Thai Spirit Cults.” American Ethnologist 39, no. 4: 766-78. https://doi.org/ 10.1111/j.1548-1425.2012.01394.x.

Kalleberg, Arne L., and Kevin Hewison

2013 "Precarious Work and the Challenge for Asia." American Behavioral Scientist 57, no. 3: 271-88. https://doi.org/10.1177/0002764212466238.

Keane, Webb

2007 Christian Moderns: Freedom and Fetish in the Mission Encounter. Berkeley: University of California Press.

Kleinman, Arthur, and Joan Kleinman

1996 "The Appeal of Experience, the Dismay of Images: Cultural Appropriations of Suffering in Our Times.” Daedalus 125, no. 1: 1-23. http://www.jstor.org/ stable/20027351.

Laidlaw, James

2002 "For an Anthropology of Ethics and Freedom." Journal of the Royal Anthropological Institute 8, no. 2: 311-32. https://doi.org/10.1111/1467-9655.00110.

2013 The Subject of Virtue: An Anthropology of Ethics and Freedom. New York: Cambridge University Press. 
Lee, Ching Kwan, and Yelizavetta Kofman

2012 “The Politics of Precarity: Views beyond the United States." Work and Occupations 39, no. 4: 388-408. https://doi.org/10.1177/0730888412446710.

Li, Tania Murray

2007 The Will to Improve: Governmentality, Development, and the Practice of Politics. Durham: Duke University Press.

2014 Land's End: Capitalist Relations on an Indigenous Frontier. Durham, N.C.: Duke University Press.

Mahmood, Saba

2005 Politics of Piety: The Islamic Revival and the Feminist Subject. Princeton, N.J.: Princeton University Press.

Marx, Karl

1975 “On the Jewish Question.” In Early Writings, translated by Rodney Livingstone and Gregory Benton, 211-241. New York: Vintage Books. Originally published in 1843.

Mills, Mary Beth

1997 "Contesting the Margins of Modernity: Women, Migration, and Consumption in Thailand." American Ethnologist 24, no. 1: 37-61. https://doi.org/10.1525/ ae.1997.24.1.37.

1999 Thai Women in the Global Labor Force: Consuming desires, Contested selves. New Brunswick, N.J.: Rutgers University Press.

Molé, Noelle J.

2013 “Existential Damages: The Injury of Precarity Goes to Court." Cultural Anthropology 28, no. 1: 22-43. https://doi.org/10.1111/j.1548-1360.2012. 01171.x.

Muehlebach, Andrea

2012 The Moral Neoliberal: Welfare and Citizenship in Italy. Chicago: University of Chicago Press.

2013 "On Precariousness and the Ethical Imagination: The Year 2012 in Sociocultural Anthropology." American Anthropologist 115, no. 2: 297-311. https://doi.org/ 10.1111/aman.12011.

Neilson, Brett, and Ned Rossiter

2008 "Precarity as a Political Concept, or, Fordism as Exception.” Theory, Culture, and Society 25, nos. 7-8: 51-72. https://doi.org/10.1177/0263276408097796.

Ong, Aihwa

2006 Neoliberalism as Exception: Mutations in Citizenship and Sovereignty. Durham, N.C.:

Duke University Press.

Pasuk, Phongpaichit, and Chris Baker

1998 Thailand's Boom and Bust. Chiang Mai, Thailand: Silkworm Books.

2002 Thailand: Economy and Politics. 2nd edition. New York: Oxford University Press.

Pasuk, Phongpaichit, and Chris Baker, eds.

2008 Thai Capital: After the 1997 Crisis. Chiang Mai, Thailand: Silkworm Books.

Pattana, Kitiarsa

2006 "Village Transnationalism: Transborder Identities among Thai-Isan Migrant Workers in Singapore." Asia Research Institute Working Paper Series, no. 71. https://ari.nus.edu.sg/Publication/Detail/577.

Persons, Larry $\mathrm{S}$.

2016 The Way Thais Lead: Face as Social Capital. Chiang Mai, Thailand: Silkworm Books.

Peters, Michael A.

2001 Poststructuralism, Marxism, and Neoliberalism: Between Theory and Politics. Lanham, Md.: Rowman and Littlefield.

Polanyi, Karl

1944 The Great Transformation: The Political and Economic Origins of Our Time. New York: Farrar and Rinehart. 
Riesman, Paul

1977 Freedom in Fulani Social Life: An Introspective Ethnography. Chicago: University of Chicago Press.

Rigg, Jonathan, Suriya Veeravongs, Lalida Veeravongs, and Piyawadee Rohitarachoon

2008 "Reconfiguring Rural Spaces and Remaking Rural Lives in Central Thailand." Journal of Southeast Asian Studies 39, no. 3: 355-81. https://doi.org/10.1017/ S0022463408000350.

Roberts, Alasdair

2010 The Logic of Discipline: Global Capitalism and the Architecture of Government. New York: Oxford University Press.

Rose, Nikolas

1999 Powers of Freedom: Reframing Political Thought. New York: Cambridge University Press.

Roseberry, William

1994 "Hegemony and the Language of Contention." In Everyday Forms of State Formation: Revolution and the Negotiation of Rule in Modern Mexico, edited by Gilbert M. Joseph

Santoro, Emilio and Daniel Nugent, 355-66. Durham, N.C.: Duke University Press.

2003 Autonomy, Freedom, and Rights: A Critique of Liberal Subjectivity. Boston: Kluwer Academic.

Sauwalak, Kittiprapas

2002 "Social Impacts of Financial and Economic Crisis in Thailand." Report, East Asian Development Network Regional Project on the Social Impact of the Asian Financial Crisis.

Slocum, Karla

2006 Free Trade and Freedom: Neoliberalism, Place, and Nation in the Caribbean. Ann Arbor: University of Michigan Press.

Smith, Gavin

2004 "Hegemony: Critical Interpretations in Anthropology and Beyond." Focaal, no. 43: 99-120. https://doi.org/10.3167/092012904782311425.

2011 "Selective Hegemony and Beyond_Populations with 'No Productive Function': A Framework for Enquiry.” Identities 18, no. 1: 2-38. https://doi.org/10. 1080/1070289X.2011.593413.

Sopranzetti, Claudio

2012 "Burning Red Desires: Isan Migrants and the Politics of Desire in Contemporary Thailand." Journal of Southeast Asia Research 20, no. 3: 361-79. https://doi.org/ 10.5367 /sear.2012.0112.

2014 "Owners of the Map: Mobility and Mobilization among Motorcycle Taxi Drivers in Bangkok." City and Society 26, no. 1: 120-46. https://doi.org/10.1111/ ciso. 12030 .

Forthcoming The Owners of the Map: Mobility and Politics in Bangkok. Oakland: University of California Press.

Stiglitz, Joseph E.

2002 Globalization and Its Discontents. New York: W. W. Norton.

van der Veer, Peter

2001 Imperial Encounters: Religion and Modernity in India and Britain. Princeton, N.J.: Princeton University Press.

Viswanathan, Gauri

1998 Outside the Fold: Conversion, Modernity, and Belief. Princeton, N.J.: Princeton University Press.

Walker, Andrew

2012 Thailand's Political Peasants: Power in the Modern Rural Economy. Madison: University of Wisconsin Press.

Warr, Peter, ed.

2005 Thailand Beyond the Crisis. New York: RoutledgeCurzon. 
Williams, Raymond

1977 Marxism and Literature. New York: Oxford University Press. Žižek, Slavoj

1989 The Sublime Object of Ideology. New York: Verso. 